\title{
HUBUNGAN PERSONAL HYGIENE DENGAN RESIKO KECACINGAN PADA SISWA SEKOLAH DASAR NEGERI
}

\author{
Samuel Marganda Manalu, Citrayuni Saragih \\ Fakultas Kesehatan Masyarakat \\ Institut Kesehatan Deli Husada Delo Tua \\ e-mail :samuelmhm@gmail.com
}

\begin{abstract}
Worm disease is a contagious disease and is a type of disease that is mostly experienced by children in Indonesia, which accounts for $80 \%$. Personal hygiene, especially at the age of elementary school children, is very important, considering that at this age intestinal worm infections transmitted through the soil are very high. The aims of this study to determine the relationship of personal hygiene with the risk of helminthiasis in Elementry School. This research using quantitative with the type of research that is observational survey. The population in this study were all students of Elementry School and the sample of 77 peoples, the total sampling technique and method of collecting data by interviewing indirectly using a questionnaire sheet. The analysis of data is using chi-square then obtained a value of $p=0.037<a=0.05$ there was a relationship between personal hygiene and the risk of worms. For this reason, it is hoped that the school will provide knowledge about personal hygiene such as every bath must use soap, wash hands with soap after defecation, wear footwear when playing outdoors, cut children's nails once a week, use clean drinking water, drink wellcooked water, not defecating in any place, providing latrines and clean water for school children to prevent worm infections.
\end{abstract}

Keywords: Personal Hygiene, Risk of Worms

\section{PENDAHULUAN}

Kecacingan merupakan penyakit yang banyak dialami oleh anak-anak di Indonesia dengan jumlah mencapai $80 \%$. Lebih dari 1,5 miliar orang atau $24 \%$ dari populasi di dunia terinfeksi Soil Transmitted Helminths (World Health Organization). Lebih dari 270 juta anak usia pra-sekolah dan 600 juta anak pada usia sekolah terinfeksi Soil Transmitted Helminths dan membutuhkan perlakuan intensif. Penyebaran infeksi tersebar di daerah tropis dan subtropis, dengan jumlah sebesar di wilayah Afrika, Amerika, Cina dan Asia Timur. Angka prevalensi kecacingan di pada 2012 masih sangat tinggi yakni $76,6 \%$ (World Health Organization).

Pada anak SD, prevalensi kecacingan masih sangat tinggi yakni $28,12 \%$, rendahnya pengetahuan masyarakat mengenai kecacingan, kurangnya kemampuan petugas untuk penanggulangan kecacingan, serta komitmen dari penetap kebijakan (Dinkes, 2017). 
Penelitian

sebelumnya

menemu-kan adanya hubungan antara kejadian kecacingan pada anak dengan personal hygiene dengan hasil adanya hubungan personal hygiene dengan $p<0,05$.

Lingkungan sekolah adalah tempat yang berpotensi besar terhadap kejadian kecacingan. Lingkungan sekolah yang masih bersemak dan halaman sekolah masih terbuat dari tanah memungkinkan telur cacing banyak berkembang dengan baik. Sedangkan hampir semua siswa/siswi di sekolah tersebut bermain di tanah dan sebagian bermain tanpa menggunakan alas kaki yaitu sebanyak 77 orang. Sarana dan prasarana mencuci tangan belum tersedia, serta penyediaan air bersih juga terbatas.

Berdasarkan hal tersebut, penting bagi peneliti untuk melihat hubungan antara personal hygiene dengan risiko kecacingan pada siswa sekolah dasar.

Berdasarkan uraian diatas maka peneliti tertarik untuk melakukan penelitian tentang Hubungan Personal Hygiene Dengan Resiko Kecacingan Pada Siswa Sekolah Dasar.

\section{METODE PENELITIAN}

Jenis Penelitian ini adalah penelitian Observasional Analitik dengan system pendekatan cross sectional, yaitu dengan cara pendekatan, observasi, atau pengumpulan data sekaligus pada suatu saat yang sama. (Notoadmodjo, 2010).

Penelitian ini dilakukan di sekolah dasar pada bulan SeptemberFebruari 2019 dengan populasi yakni seluruh siswa sekolah dasar yakni 77 orang dan dengan menggunakan seluruh siswa sebagai sampel.

\section{HASIL DAN PEMBAHASAN}

Data diolah dan disajikan kedalam tabel, distribusi sebagai berikut ini. Berdasarkan tabel 4.1 Distribusi frekuensi jenis kelamin laki - laki sebanyak 34 orang dengan persentase $(44,2 \%)$, dan responden berjenis kelamin perempuan yaitu sebanyak 43 orang dengan persentase $(55,8 \%)$. Sedangkan distribusi frekuensi berdasarkan umur, responden dengan umur 10 - 12 tahun sebanyak 48 orang dengan persentase $(62,3 \%)$, dan responden umur 6 - 9 tahun yaitu sebanyak 29 orang dengan persentase $(37,7 \%)$.

\section{A. Karakteristik Responden}

Tabel 3.1 Karakteristik Responden

\begin{tabular}{ccc}
\hline $\begin{array}{c}\text { Karakteri } \\
\mathrm{s}\end{array}$ & $\mathrm{F}$ & $\%$ \\
tik & & \\
\hline Jenis & & \\
Kelamin & & \\
Laki laki & 34 & 44,2 \\
Perempua & 43 & 55,8 \\
$\mathrm{n}$ & & \\
Total & 77 & 100 \\
\hline Umur & & \\
6-9 Tahun & 29 & 37,7 \\
10-12 & 48 & 62,3 \\
Tahun & & \\
Total & & \\
\hline
\end{tabular}

\section{B. Analisis Univariat}

Berdasarkan tabel 4.2 menunjukkan responden dengan kebiasaan mencuci tangan yang buruk sebanyak 44 orang $(57,1 \%)$. Responden yang memiliki kebiasaan 
memakai alas kaki buruk yaitu sebanyak 43 orang dengan persentase $(55,8 \%)$. Responden yang memiliki kebersihan kuku dengan kategori buruk yaitu sebanyak 42 orang dengan persentase ( 54,5 \%). Responden dengan kebersihan jajan yang tidak bersih yaitu sebanyak 40 orang dengan persentase (51,9\%). Responden dengan kebiasaan defekasi buruk yaitu sebanyak 40 orang dengan persentase ( $51,9 \%$ ). Responden yang beresiko kecacingan sebanyak 43 orang dengan persentase $(55,8 \%)$

Tabel 3.2 Kebiasaan Cuci Tangan, Menggunakan Alas Kaki, Kebersihan Kuku, Kebersihan Jajan, Kebiasaan Defekasi, dan Resiko Kecacingan

\begin{tabular}{lcc}
\hline Variabel & F & $\%$ \\
\hline Cuci tangan & & \\
Baik & 33 & 42,9 \\
Buruk & 44 & 57,1 \\
\hline Total & 77 & 100 \\
\hline Alas Kaki & & \\
\hline Baik & 34 & 44,2 \\
Buruk & 43 & 55,8 \\
\hline Total & 77 & 100 \\
\hline Kebersihan Kuku & \\
\hline Baik & 35 & 45,5 \\
\hline Buruk & 42 & 54,5 \\
\hline Total & 77 & 100 \\
\hline Kebersihan Jajan & 51,9 \\
\hline Bersih & 37 & 48,1 \\
\hline Tidak Bersih & 40 & \\
\hline
\end{tabular}

\begin{tabular}{lcc}
\hline Total & 77 & 100 \\
\hline \multicolumn{2}{l}{ Kebiasaan } & Defekasi \\
\hline Baik & 37 & 48,1 \\
Buruk & 40 & 51,9 \\
\hline Total & 77 & 100 \\
\hline Resiko Kecacingan & \\
\hline Beresiko & 43 & 55,8 \\
Tidak & 34 & 44,2 \\
Beresiko & & \\
\hline Total & 77 & 100 \\
\hline
\end{tabular}

\section{Analisis Bivariat}

Berdasarkan tabel dibawah ini menunjukkan responden yang memiliki kebiasaan mencuci tangan dengan kategori buruk lebih banyak beresiko kecacingan. Hasil uji statistik dengan menggunakan chi-square ( $p$-value) sebesar 0,006 < a = 0,05 yang menunjukkan bahwa ada hubungan yang signifikan antara mencuci tangan dengan resiko kecacingan di Sekolah Dasar .

Tabel 3.3 Tabel Hubungan antara cuci tangan dengan resiko kecacingan

\begin{tabular}{|c|c|c|c|c|c|c|c|}
\hline \multirow{3}{*}{$\begin{array}{l}\text { Cuci } \\
\operatorname{tang} \\
\text { an }\end{array}$} & \multicolumn{7}{|c|}{ Resiko Kecacingan } \\
\hline & \multicolumn{2}{|c|}{ Beresiko } & \multicolumn{2}{|c|}{$\begin{array}{l}\text { Tidak } \\
\text { Beresik } \\
\text { o }\end{array}$} & \multicolumn{2}{|c|}{ Total } & $\begin{array}{l}\mathrm{p}- \\
\text { valu } \\
\mathrm{e}\end{array}$ \\
\hline & $\mathrm{F}$ & $\%$ & $\mathrm{~F}$ & $\%$ & $\mathrm{~F}$ & $\%$ & \\
\hline Baik & 12 & $\begin{array}{l}36 . \\
4\end{array}$ & $\begin{array}{l}2 \\
1\end{array}$ & $\begin{array}{l}63 . \\
6\end{array}$ & $\begin{array}{l}3 \\
4\end{array}$ & $\begin{array}{l}10 \\
0\end{array}$ & $\begin{array}{l}0,00 \\
6\end{array}$ \\
\hline $\begin{array}{l}\text { Buru } \\
\mathrm{k}\end{array}$ & 31 & $\begin{array}{l}70 . \\
5\end{array}$ & $\begin{array}{l}1 \\
3\end{array}$ & $\begin{array}{l}29 . \\
5\end{array}$ & $\begin{array}{l}4 \\
4\end{array}$ & $\begin{array}{l}10 \\
0\end{array}$ & \\
\hline Total & 43 & $\begin{array}{l}55 . \\
8\end{array}$ & $\begin{array}{l}3 \\
4\end{array}$ & $\begin{array}{l}44 . \\
2\end{array}$ & $\begin{array}{l}7 \\
7\end{array}$ & $\begin{array}{l}10 \\
0\end{array}$ & \\
\hline
\end{tabular}

Berdasarkan tabel di bawah ini menunjukkan bahwa responden yang memiliki kebiasaan memakai alas kaki ketika di luar rumah/ bermain dengan 
kategori buruk lebih banyak yang beresiko kecacingan. Hasil uji statistik dengan menggunakan chisquare ( $p$ - value) sebesar 0,037< $a=0,05$ yang menunjukkan bahwa ada hubungan yang signifikan antara memakai alas kaki dengan resiko kecacingan di Sekolah Dasar.

Tabel 3.4 Tabel Hubungan antara Alas Kaki dengan resiko kecacingan

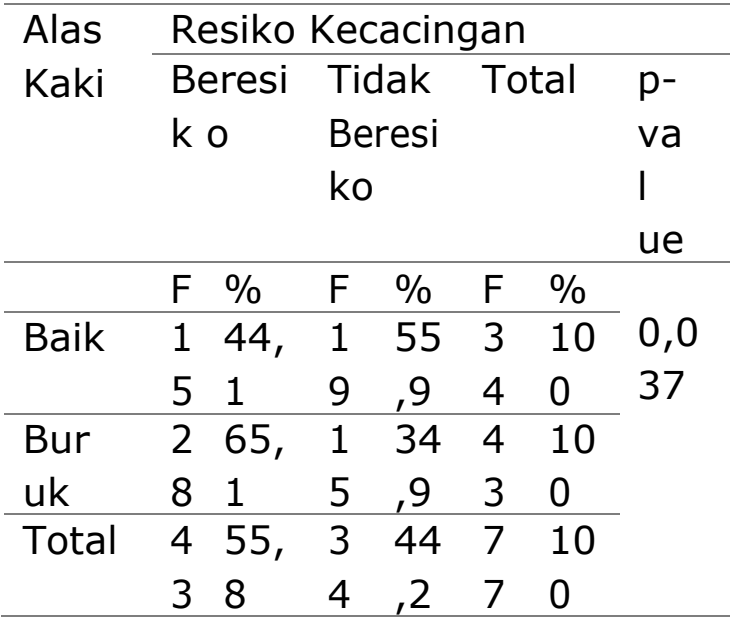

Berdasarkan tabel di bawah ini menunjukkan bahwa responden yang memiliki kuku dengan kategori buruk lebih beresiko kecacingan. Hasil uji statistik dengan menggunakan chisquare ( $p$-value) sebesar 0,022< 0,05 yang menunjukkan bahwa ada hubungan yang signifikan antara kebersihan kuku dengan resiko kecacingan di Sekolah Dasar .

\begin{tabular}{|c|c|c|c|c|}
\hline \multirow{3}{*}{$\begin{array}{l}\text { Keber } \\
\text { sihan } \\
\text { Jajan }\end{array}$} & \multicolumn{2}{|c|}{$\begin{array}{c}\text { Resiko } \\
\text { Kecacingan }\end{array}$} & \multirow[b]{2}{*}{ Total } & \multirow[b]{2}{*}{$\begin{array}{l}\mathrm{p}- \\
\text { val } \\
\text { ue }\end{array}$} \\
\hline & $\begin{array}{l}\text { Bere } \\
\text { siko }\end{array}$ & $\begin{array}{c}\text { Tidak } \\
\text { Beres } \\
\text { iko }\end{array}$ & & \\
\hline & $F$ & $F$ & $F$ & \\
\hline Baik & 16 & 21 & 37 & \multirow{3}{*}{0,007} \\
\hline Buruk & 27 & 13 & 40 & \\
\hline Total & 43 & 34 & 77 & \\
\hline
\end{tabular}

Tabel 3.5 Tabel Hubungan antara

Kebersihan Kuku dengan resiko kecacingan

\begin{tabular}{|c|c|c|c|c|}
\hline \multirow{3}{*}{$\begin{array}{l}\text { Keber } \\
\text { sihan } \\
\text { Kuku }\end{array}$} & \multicolumn{2}{|c|}{$\begin{array}{c}\text { Resiko } \\
\text { Kecacingan }\end{array}$} & \multirow[b]{2}{*}{ Total } & \multirow[b]{2}{*}{$\begin{array}{l}\mathrm{p}- \\
\text { val } \\
\text { ue }\end{array}$} \\
\hline & $\begin{array}{l}\text { Bere } \\
\text { siko }\end{array}$ & $\begin{array}{c}\text { Tidak } \\
\text { Beres } \\
\text { iko }\end{array}$ & & \\
\hline & $\mathrm{F}$ & $\mathrm{F}$ & $\mathrm{F}$ & \\
\hline Baik & 10 & 25 & 35 & \multirow{3}{*}{0,022} \\
\hline Buruk & 33 & 9 & 42 & \\
\hline Total & 43 & 34 & 77 & \\
\hline
\end{tabular}

Berdasarkan tabel dibawah ini menunjukkan bahwa responden yang memiliki jajan tidak bersih lebih banyak beresiko kecacingan. Hasil uji statistik dengan menggunakan chisquare ( $p$ - value) sebesar 0,007 $<a=$ 0,05 yang menunjukkan bahwa ada hubungan yang signifikan antara kebersihan jajan dengan resiko kecacingan di Sekolah Dasar.

Tabel 3.6 Tabel Hubungan antara Kebersihan Jajan dengan resiko kecacingan

\begin{tabular}{|c|c|c|c|c|}
\hline \multirow{3}{*}{$\begin{array}{l}\text { Keber } \\
\text { sihan } \\
\text { Kuku }\end{array}$} & \multicolumn{2}{|c|}{ Resiko Kecacingan } & \multirow[b]{2}{*}{$\begin{array}{c}\text { Tot } \\
\text { al }\end{array}$} & \multirow[b]{2}{*}{$\begin{array}{l}\mathrm{p}- \\
\text { val } \\
\text { ue }\end{array}$} \\
\hline & $\begin{array}{c}\text { Beresi } \\
\text { ko }\end{array}$ & $\begin{array}{c}\text { Tidak } \\
\text { Beresi } \\
\text { ko }\end{array}$ & & \\
\hline & $\mathrm{F}$ & $\mathrm{F}$ & $\mathrm{F}$ & \\
\hline Baik & 16 & 21 & 37 & \multirow{3}{*}{0,007} \\
\hline Buruk & 27 & 13 & 40 & \\
\hline Total & 43 & 34 & 77 & \\
\hline
\end{tabular}

Berdasarkan tabel di bawah ini menunjukkan bahwa responden yang memiliki kebiasaan defekasi/ BAB buruk lebih cenderung beresiko kecacingan. Hasil uji statistik dengan ( $p$-value) sebesar 0,007 $<a=0,05$ yang menunjukkan bahwa ada hubungan yang signifikan antara kebiasaan defekasi/ BAB dengan resiko kecacingan di Sekolah Dasar . 
Tabel 3.7 Tabel Hubungan Kebiasaan Defekasi/ BAB dengan resiko kecacingan

\begin{tabular}{|c|c|c|c|c|c|c|c|}
\hline \multirow{3}{*}{$\begin{array}{c}\text { Kebias } \\
\text { aan } \\
\text { Defeka } \\
\text { si/BAB }\end{array}$} & \multicolumn{7}{|c|}{ Resiko Kecacingan } \\
\hline & \multicolumn{2}{|c|}{$\begin{array}{c}\text { Beresi } \\
\text { ko }\end{array}$} & \multicolumn{2}{|c|}{$\begin{array}{c}\text { Tidak } \\
\text { Beresi } \\
\text { ko } \\
\end{array}$} & \multicolumn{2}{|c|}{ Total } & $\begin{array}{c}p- \\
\text { valu } \\
e\end{array}$ \\
\hline & $\mathrm{F}$ & $\%$ & $\mathrm{~F}$ & $\%$ & $\mathrm{~F}$ & $\%$ & \\
\hline Baik & 16 & $\begin{array}{l}43 \\
, 2\end{array}$ & 21 & $\begin{array}{l}56 \\
88\end{array}$ & 37 & $\begin{array}{c}10 \\
0\end{array}$ & 0,007 \\
\hline Buruk & 27 & $\begin{array}{l}67 \\
, 5\end{array}$ & 13 & $\begin{array}{r}32 \\
, 5\end{array}$ & 40 & $\begin{array}{c}10 \\
0\end{array}$ & \\
\hline Total & 43 & $\begin{array}{r}55 \\
8\end{array}$ & 34 & $\begin{array}{l}44 \\
, 2\end{array}$ & 77 & $\begin{array}{c}10 \\
0\end{array}$ & \\
\hline
\end{tabular}

\section{PEMBAHASAN Hubungan Mencuci Tangan dengan Resiko Kecacingan}

Berdasarkan analisis menggunakan uji Chi Square antara kebiasaan mencuci tangan dengan kecacingan, diperoleh nilai $p(0,006)$ lebih kecil dari nilai a $(0,05)$, artinya $\mathrm{Ha}$ diterima, terdapat hubungan antara kebiasaan mencuci tangan dengan kejadian cacingan. Hasil penelitian ini menunjukkan bahwa di Sekolah Dasar menyimpulkan bahwa menunjukkan bahwa responden yang memiliki kebiasaan mencuci tangan dengan kategori baik yang beresiko kecacingan yaitu sebanyak 12 orang dengan persentase ( $36,4 \%)$, dan responden yang memiliki kebiasaan mencuci tangan dengan kategori baik tidak tetapi beresiko kecacingan adalah sebanyak 21 orang dengan persentase $(63,6 \%)$. Sedangkan responden yang memiliki kebiasaan mencuci tangan dengan kategori buruk beresiko sebanyak 31 orang dengan persentase $(70,5 \%)$, dan responden yang memiliki kebiasaan mencuci tangan dengan kategori buruk dan tidak beresiko kecacingan adalah sebanyak 13 orang dengan persentase (29,5\%). Cacingan merupakan salah satu penyakit yang berbasis lingkungan, oleh sebab itu perlu perhatian terhadap sanitasi lingkungan. Infeksi cacing perut akan berkurang bahkan dapat dihilangkan sama sekali apabila menerapkan perilaku hidup bersih dan sehat seperti mencuci tangan dengan sabun pada saat setelah buang air besar, membersihkan anak yang $B A B$, sebelum menyiapkan makanan, sebelum makan, setelah menyentuh hewan, dan mengelola makanan secara baik, menciptakan lingkungan yang bersih ,makanan bergizi. Yang dapat mencapai pembangunan pengentasan kemiskinan.

\section{Hubungan Memakai Alas Kaki Dengan Resiko Kecacingan}

Hasil penelitian menunjukkan responden yang memiliki kebiasaan memakai alas kaki buruk yaitu 43 orang dengan persentase (55,8 \%), dan. Hasil penelitian ini menunjukkan bahwa responden yang memiliki kebiasaan memakai alas kaki ketika di luar rumah/ bermain dengan kategori baik yang beresiko kecacingan yaitu sebanyak 15 orang dengan persentase ( $44,1 \%)$, dan responden yang memiliki kebiasaan memakai alas kaki dengan kategori baik tidak beresiko kecacingan adalah sebanyak 19 orang dengan persentase $(55,9 \%)$. Sedangkan responden yang memiliki kebiasaan memakai alas kaki dengan kategori buruk beresiko kecacingan sebanyak 28 orang dengan persentase $(65,1 \%)$, dan responden yang memiliki kebiasaan memakai alas kaki dengan kategori buruk yang tidak beresiko kecacingan adalah sebanyak 15 orang dengan persentase $(34,9 \%)$. 
Setelah melakukan analisis data, menunjukkan $\rho$ value < $\mathrm{a}=0,05 \quad(\rho=0,037)$, artinya $\mathrm{Ha}$ diterima atau dapat dikatakan bahwa terdapat hubungan antara kebiasaan memakai alas kaki dengan kejadian cacingan. Menjaga dan memelihara kebersihan kaki sangatlah penting karena kaki dapat menjadi jalan masuk kuman penyakit ke dalam tubuh manusia, diantaranya telur cacing. Karena itu, penggunaan alas kaki dapat mencegah telur cacing masuk sehingga menurunkan kejadian kecacingan. Kelompok rentan terinfeksi cacing adalah anak sekolah karena memiliki kebiasan untuk bermain dengan aktifitas langsung berhubungan langsung dengan tanah. Pada saat yang sama, mereka lupa untuk menggunakan alas kakinya.

\section{Hubungan Antara Kebersihan Kuku Dengan Kejadian Cacingan}

Berdasarkan analisis kebersihan kuku dengan kejadian cacingan diperoleh hasil responden yang memiliki kuku dengan kategori baik beresiko kecacingan sebanyak 10 orang dengan persentase $(28, \%)$, dan responden yang memiliki kuku dengan kategori baik tetapi tidak beresiko kecacingan adalah sebanyak 25 orang dengan persentase $(71,4$ $\%)$. Sedangkan responden yang memiliki kuku dengan kategori buruk beresiko kecacingan sebanyak 33 orang dengan persentase $(78,5 \%)$, dan responden yang memiliki kuku dengan kategori buruk sebanyak 9 orang dengan persentase $(21,5 \%)$ tidak beresiko kecacingan. Hasil uji statistik chi- square didapatkan $\rho$ value $<0,05(\rho=0,022)$, artinya $\mathrm{Ha}$ diterima, terdapat hubungan antara kebersihan kuku dengan kejadian cacingan. Anak-anak memiliki kebiasaan mencuci tangan sebelum makan, namun jarang untuk memotong kuku mereka minimal satu kali seminggu sehingga risiko terjadinya kecacingan lebih besar karena penularan dapat terjadi melalui makanan yang terkontaminasi telur cacing karena tidak terbungkus dengan baik maupun terpapar oleh debu yang didalamnya dapat mengandung telur cacing.

\section{Hubungan Kebersihan Makanan Jajanan Dengan Kejadian Kecacingan}

Dari 77 responden yang memiliki jajan bersih dan beresiko kecacingan sebanyak 16 orang dengan persentase ( 43,2 \% ), dan responden yang memiliki jajan bersih tidak beresiko kecacingan adalah sebanyak 21 orang dengan persentase (56,8\%). Sedangkan responden yang memiliki jajan tidak bersih beresiko kecacingan sebanyak 27 orang dengan persentase $(67,5 \%)$, dan responden yang memiliki kuku tidak bersih dan tidak beresiko kecacingan adalah sebanyak 13 orang dengan persentase $(32,5 \%)$. Berdasarkan uji statistik, diperoleh hasil $\rho$ value $<0,05(\rho=0,007)$, artinya $\mathrm{Ha}$ diterima, terdapat hubungan antara kebersihan jajanan dengan kejadian cacingan. Kebanyakan anak usia sekolah suka jajan (95\%), namun mereka membeli jajan disembarang tempat yang tidak higienis dan tidak terbungkus atau tertutup yang dapat menyebabkan anak mengalami kecacingan. Hal ini disebabkan penularan telur cacing dapat melalui makanan yang tidak terbungkus sehingga dihinggapi lalat atau tercemar oleh debu atau tanah yang mengandung telur cacing. 


\section{Hubungan Antara Kebiasaan Defekasi/BAB Dengan Resiko Cacingan}

Hasil penelitian menunjukkan bahwa dari 77 responden yang memiliki kebiasaan defekasi/ BAB baik beresiko kecacingan sebanyak 16 orang dengan persentase $(43,2 \%)$, dan responden yang memiliki kebiasaan setelah defekasi/ BAB baik tidak beresiko kecacingan adalah sebanyak 21 orang dengan persentase (56,8\%). Sedangkan responden yang memiliki memiliki kebiasaan defekasi/BAB buruk beresiko kecacingan sebanyak 27 orang dengan persentase $(67,5 \%)$, dan responden yang memiliki kebiasaa defekasi/ BAB buruk dan tidak beresiko kecacingan adalah sebanyak 13 orang dengan persentase $(32,5 \%)$.

Melalui hasil uji statistik chi-square didapatkan $\rho$ value $<a$ $0,05 \quad(\rho=0,007)$, artinya $\mathrm{Ha}$ diterima, terdapat hubungan antara kebiasaan defekasi/BAB dengan kejadian cacingan. Mencegah penyakit kecacingan dapat dilakukan dengan berbagai upaya, antara lain mencuci tangan dengan menggunakan sabun setelah selesai bermain, sebelum memegang makanan, dan selalu menggunakan alas kaki.

\section{KESIMPULAN}

1. Terdapat hubungan signifikan antara Mencuci Tangan dengan Resiko kecacingan Pada siswa/ siswi Sekolah Dasar ( $p$-value = 0,006)

2. Terdapat hubungan signifikan antara Memakai Alas Kaki dengan Resiko kecacingan Pada siswa/ siswi Sekolah Dasar ( $p$-value $=$ 0,037)

3. Terdapat hubungan signifikan antara Kebersihan Kuku dengan Resiko kecacingan Pada siswa/ siswi Sekolah Dasar $(p$-value $=0,022)$.

4. Terdapat hubungan signifikan antara Kebersihan Jajan dengan Resiko Kecacingan Pada siswa/ siswi Sekolah Dasar ( $p$-value $=0,007$ )

5. Terdapat hubungan signifikan antara Kebiasaan Defekasi/ BAB dengan Resiko kecacingan Pada siswa/ siswi Sekolah Dasar ( $p$-value $=0,007)$.

\section{DAFTAR PUSTAKA}

Erlina Yuni, Natalia.2016. Personal Hygiene. Yogyakarta: Nuha Medika.

Ditjen P2P. 2015. Rencana Aksi Pengendalian Penyakir Dan Penyehatan Lingkungan.Jakarta. Ditjen P2P.

FKUI, Departemen Parasitilogi. 2013. Parasitologi Kedokteran. Jakarta: Badan Penerbit FKUI.

Irawati. 2013. Hubungan Personal Hygiene dengan Kecacingan Pada Anak. FKM. UIN Alauddin. Makassar.

Permenkes. 2017. Peraturan Menteri Kesehatan Tentang Penanggulangan Cacingan. Jakarta: Permenkes

Rizka. dkk. 2013. Hubungan Antara Hygiene Perorangan Dengan Infeksi Cacing Pada Siswa Sedolah Dasar Negeri 25 Dan 28 Di Padang. Fakultas Ilmu kesehatan.Unand Padang Sumatera Barat. 
Sefrina, Andin dan Suhendri Cahya Purnama.2012. Mengenal, Mencegah, Menangani Berbagai Penyakit

Berbahaya Bayi dan Balita.Jakarta: Dunia Sehat.

Sutawijaya, Risang Bagus. 2017. Mencegah, Mendeteksi dan Mengatasi Penyakit Anak. Yogyakarta: Luna Publisher.

Swasanti, Niluh dan Winkanda Satria Putra. 2017. Pertolongan Pertama Pada Anak Sakit. Yogyakarta: Katahati.

Tarigan, Lidya Devega. 2017. Hubungan Ketersediaan Jamban Dan Personal Hygiene Terhadap Infeksi Kecacingan Pada Anak Di Sekolah Dasar Negeri Kelurahan Pulau Sicanang Kecamatan Medan Belawan. Fakultas Kesehatan Masyarakat. Universitas Sumatera Utara. 